\title{
TANGGUNG JAWAB PEMERINTAH DAERAH DALAM PEMBERIAN IZIN PERTAMBANGAN BAHAN GALIAN BATUAN SERTA PENGENDALIAN DAMPAKNYA DI KABUPATEN LOMBOK TIMUR
}

\author{
Maidy \\ Fakultas Hukum Universitas Gunung Rinjani \\ e-mail: maidy.ugr2014@gmail.com
}

\section{Info Artikel}

Sejarah Artikel :

Diterima 11 April 2021

Disetujui 2 Mei 2021

Publikasi Mei 2021

\section{Keyword:}

Supervision; Mining Exciting Materials; Mining license

\section{Alustract}

This study aims to determine the role of local government in supervising rock mining activities as well as the factors that influence the existence of rock mining activities in East Lombok Regency. Research using juridical empirical legal method means that a study examines problems according to facts that occur in the field and studies of legislation. The results show that the East Lombok Regency Government no longer has the authority to supervise mining which has been taken over by the Provincial Government since the issuance of Law Number 23 of 2014 concerning Regional Government which hampers the mining supervision and licensing process. Both miners and mining owners are made difficult in applying for permits because business owners have to apply for mining permits to the Provincial Government, this is one of the factors that causes the large number of illegal rock mining activities to occur in East Lombok Regency.

\section{Ahstrak}

Penelitian ini bertujuan untuk mengetahui Peranan Pemerintah daerah dalam pengawasan kegiatan pertambangan bahan galian batuan serta faktor yang mempengaruhi adanya kegiatan penambangan bahan galian batuan di Kabupaten Lombok Timur. Penelitian menggunakan Metode hukum juridis empiris artinya suatu penelitian mengkaji permasalahan sesuai fakta yang terjadi di lapangan dan kajian perundangundnagan. Hasil penelitian menunjukan Pemda Kabupaten Lombok Timur tidak lagi memiliki kewenangan dalam pengawasan pertambangan dimana sudah diambil alih oleh Pemerintah Daerah Provinsi sejak dikeluarkannya UndangUndang Nomor 23 Tahun 2014 tentang Pemerintah Daerah yang membuat proses pengawasan dan perizinan pertambangan cukup terhambat. Kedua penambang dan perusahaan pemilik pertambangan dipersulit dalam pengajuan perizinan karena para pemilik usaha harus mengurus izin pertambangan ke Pemerintah Daerah Provinsi, hal ini merupakan salah satu faktor yang menyebabkan banyaknya kegiatan pertambangan bahan galian batuan ilegal terjadi di Kabupaten Lombok Timur. 


\section{A. PEndahuluan}

Sejarah Pertambangan di Indonesia telah ada sejak Indonesia belum merdeka. Pertama kali dilakukan pada tahun 1871 oleh Pengusaha asal Belanda bernama Jan Reerink dengan melakukan eksploitasi minyak secara komersil di Lereng Gunung Ciremai Jawa Barat. ${ }^{1}$

Setelah Kemerdaan dengan mengacu pada Pasal 33 ayat (3) Undang-Undang Dasar Tahun 1945 yang berbunyi "Bumi, air dan kekayaan alam yang terkandung di dalamnya dikuasai oleh negara dan dipergunakan untuk sebesar-besarnya kemakmuran rakyat", maka sektor Pertambangan dikuasai oleh negara. Dalam hal ini, negara memiliki kekuasaan dalam menentukan siapa yang berhak atau tidak berhak melakukan usaha Pertambangan.

Saat ini kegiatan Pertambangan yang lebih dikenal di Indonesia adalah pertambangan untuk komiditas mineral logam, antara lain emas, tembaga, nikel, bauksit dan komoditas batubara. Selain komoditas mineral utama dan batubara ini, komoditas batuan atau pertambangan batuan memiliki peran yang sama pentingnya terutama dalam memberikan dukungan material untuk pembangunan infrastruktur.

Berdasarkan istilah dalam UndangUndang Nomor 11 tahun 1967 tentang ketentuan-ketentuan pokok Pertambangan, Pasal 3 disebutkan bahan-bahan galian dibagi atas tiga golongan :

a. Golongan bahan galian strategis;

b. Golongan bahan galian vital;

c. Golongan bahan galian yang tidak termasuk dalam goongan a atau b.

Terminologi bahan galian Golongan $\mathrm{C}$ yang sebelumnya diatur dalam UndangUndang Nomor 11 tahun 1967 tersebut telah diubah berdasarkan Undang-Undang Nomor 4 tahun 2009 menjadi batuan.

Kegiatan Pertambangan batuanpun marak dilakukan diberbagai Wilayah Indonesia. Salah satunya di Wilayah kabupaten Lombok Timur. Lombok Timur merupakan daerah tingkat II di Wilayah

https://id.wikipedia.org/wiki/Sejarah_perminyakan_di_Indo nesia
Provinsi Nusa Tenggara Barat. Kabupaten ini memiliki luas $2.679,88 \mathrm{Km}^{2}$ dengan daratan seluas $1.605,55 \mathrm{Km}^{2}(59,91 \%)$ dan lautan seluas $1.074,33 \mathrm{Km}^{2}$ dan populasi 1.105 .582 $\mathrm{Km}^{2}$ jiwa. Bagian Utara merupakan lereng gunung Rinjani sehingga merupakan wilayah yang subur untuk pertanian. Sedangkan bagian Selatan yang berbatasan dengan Samudra Hindia merupakan penghasil ikan dan budidaya kerang mutiara.

Selaian itu Lombok Timur juga marak dengan kegiatan pertambangan. Pajak mineral bukan logam dan batuan (MBLB) menjadi salah satu obyek pajak terbesar di Lombok Timur tahun 2017, Pemerintah Kabupaten Lombok Timur menargetkan PAD (Pendapatan Asli Daerah) dari pajak MBLB sebesar Rp. 9 miliar.

Namun selain berdampak positif bagi penerimaan daerah, Pertambangan juga memiliki dampak negatif terutama bagi lingkungan sekitar tambang. Seperti yang terjadi di akhir 2017, sebanyak 4 (empat) desa di Lombok Timur, yaitu desa Tirtanadi, desa Teko, desa Tanah Gadang dan desa Anggariksa terkena dampak Pertambangan batuan yang berlokasi di Wilayah desa Mamben kecamatan Wanasaba. Air bekas tambang batuan tersebut masuk ke lahan pertanian dan merusak tanaman milik masyarakat.

Hal tersebut menjadi dilema bagi daerah tingkat II sebagai pemerintah di Wilayah lokasi tambang, terutama sejak perizinan Pertambangan tidak lagi mejadi wewenang kabupaten untuk menerbitkan namun wewenang tersebut dipindahkan ke Provinsi.

Undang-Undang Nomor 4 tahun 2009 menetapkan bahwa kewenangan Izin Usaha Pertambangan terletak pada masing-masing daerah Provinsi Kabupaten/Kota. Namun setelah adanya Undang-Undang Nomor 23 Tahun 2014 tentang pemerintahan daerah, dasar hukum kewenangan izin usaha Pertambangan di daerah berubah mutlak hanya menjadi kewenangan Gubernur sebagai wakil pemerintah pusat secara vertikal dalam rangka tugas pembantuan.

Pemerintah kabupaten Lombok Timur dalam wawancara dengan salah satu media lokal, mengaku khawatir dengan banyak tembusan izin Pertambangan yang masuk diruangannya. "itu kesalahan besar karena saat ini sangat liar Pertambangan di Lotim 
(Lombok Timur) atau di daerah lainnya. Karena Provinsi semau-maunya mengeluarkan izin. Mereka tidak tahu bagaimana kondisi di Daerah".

Kewenangan pemerintah dalam memberikan izin usaha Pertambangan, sudah seharusnya dibarengi dengan tanggung jawab mulai dari analisa dampak lingkungan, pengawasan selama berjalannya izin usaha pertimbangan hingga revitalisasi terhadap dampak yang ditimbulkan.

Seringkali rumitnya pembuatan izin usaha Pertambangan oleh pemerintah menyebabkan munculnya PertambanganPertambangan ilegal. Beberapa perusahaan nakal sering kali langsung beroperasi berbarengan dengan mengurus izin. Sehingga Analisa Dampak Lingkungan (AMDAL) yang menjadi salah satu syarat utama dapat dikeluarkan Izin usaha Pertambangan diabaikan. Pertambangan batuan pada umumnya berbeda dengan Pertambangan lainnya. Pertambangan batuan biasanya dikelola dekat dengan pemukiman warga yang berhubungan langsung dengan jalur transportasi. Pengelaolaanya memiliki risiko relatif lebih tinggi dengan dampak lingkungan yang besar seperti rusaknya hutan, rusaknya bukti dan pegunungan, rusaknya jalan serta pencemaran udara, air dan tanah. Terutama yang merasakan dampak secara langsung adalah masyarakat dan lingkungan sekitar tambang.

Selama beroperasinya

Pertambangan batuan, sangat diperlukan pengawasan pemerintah. Lokasi pertambangan yang biasanya dekat dengan pemukiman, sawah atau lahan warga, sehingga sangat berpotensi menimbulkan kerusakan lingkungan maupun konflik sosial. Limbah buangan menjadi sagat berbahaya bagi lingkungan sekitar tambang apabila tidak disalurkan secara benar. Pengangkutan yang biasanya menggunakan truk-truk besar juga sangat berpotensi merusak fasilitas umum seperti jalan.

Saat berhentinya izin usaha Pertambangan, perubahan lingkungan yang menjadi di lokasi tambang akan sangat besar. Revitalisasi lokasi bekas tambang akan menjadi pekerjaan yang berlangsung lama. Namun apabila kondisi bekas tambang dibiarkan akan mengancam keseimbangan lingkungan dan berpotensi bencana.
Pertambangan salah satu kegiatan ekonomi yang sangat menguntungkan. Namun dampak kerusakan yang ditimbulkanpun sangat besar. Oleh karena itu, penulis merasa perlu dilakukan penelitian terkait tanggung jawab pemerintah daerah dalam pemberian izin Pertambangan bahan galian batuan serta pengendalian dampaknya di Kabupaten Lombok Timur. Dari uraian yang dikemukakan dalam latar belakang masalah di atas, maka dapat dirumuskan beberapa permasalahan sebagai berikut: Pertama, Apa bentuk tanggung jawab pemerintahan Provinsi Nusa Tenggara Barat dalam pemberian izin Pertambangan bahan galian bantuan di Wilayah Lombok Timur ditinjau dari Undang-Undang Nomor 23 tahun 2014? Kedua, Bagaimana bentuk pengendalian dampak Pertambangan bahan galian batuan oleh pemerintah daerah di Wilayah Lombok Timur?

\section{B. METODELOGI PENELITIAN}

Penelitian hukum ini termasuk jenis penelitian hukum normatif dan empiris, hal ini dikarenakan penelitian ini menggunakan data primer dan sekunder dalam mengkaji dan menelusuri norma-norma serta peraturan-peraturan yang mengatur tentang perizinan dan pengendalian dampak Pertambangan. Tipe penelitian hukumnya adalah kajian komperehensif analisa terhadap bahan hukum sekunder. Hasil kajian dipaparkan secara lengkap, jelas, rinci dan sistematis mengenai pembahasan permasalahan. Pendekatan yang dilakukan dalam melakukan penelitian ini adalah: pendekatan perundang-Undangan (statue approach). Pendekatan ini dilakukan dengan menelaah semua peraturan perundangUndangan serta regulasi-regulasi yang bersangkut paut dengan izin Pertambangan batuan. Kemudian pendekatan kasus (case approach), pendekatan ini dilakukan dengan melakukan telaah pada kasus-kasus yang berkaitan dengan kegiatan Pertambangan batuan di Wilayah Kabupaten Lombok Timur. Penulis memilih lokasi penelitian di Wilayah Kabupaten Lombok Timur sebagai lokasi Pertambangan dan pemerintah Provinsi Nusa Tenggara Barat sebagai yang berwenang mengeluarkan Izin Usaha Pertambangan. Adapun alasan penulis memilih lokasi 
enelitian tersebut karena maraknya usaha Pertambangan batuan di Wilayah tersebut.

Sumber data yang akan digunakan dalam penelitian ini terdiri atas dua kategori, yaitu: (1) Data Primer yaitu data yang diperoleh angsung dari narasumber di lokasi penelitian yang berkaitan dengan izin kegiatan Pertambangan batuan dan kegiatan pengendalian dampak usaha Pertambangan batuan; dan (2) Data sekuder yaitu data yang diperoleh melalui studi kepustakaan yaitu menelaah literatur, artike, liputan, makalah serta peraturan perundang-Undangan yang ada kaitannya dengan kegiatan Pertambangan batuan di Wilayah Kabupaten Lombok Timur.

Metode pengumpulan data dilakukan dengan dua cara yaitu penelitian kepustakaan (library research), penulis melakukan pengumpulan data dengan cara membaca sejumlah literatur yang relevan dengan tanggung jawab pemerintah daerah dalam pemberian Izin Usaha Pertambangan bahan galian batuan serta pengendalian dampaknya di Kabupaten Lombok Timur. Penelitian lapangan (field research), yaitu penelitian melakukan pengumpulan data dengan observasi ke lokasi penelitian dan melakukan wawancara (interview) kepada sejumlah narasumber yang kompeten. Data penelitian diolah dan di analisis secara kualitatif yaitu menganalisa data berdasarkan kualitasnya lalu dideskripsikan dengan menggunakan kata-kata sehingga diperoleh bahasan atau paparan dalam bentuk kalimat yang sistematis dan dapat dimengerti, kemudian ditarik kesimpulan.

\section{PEMBAHASAN}

\section{Bentuk Tanggung Jawab Pemerintah Provinsi Nusa Tenggara Barat dalam Pemberian Izin Pertambangan Bahan Galian Batuan di Wilayah Lombok Timur.}

Dalam rencana tata ruang dan Wilayah (RTRW) Nusa Tenggara Barat, telah disepakatai ada dua pula pendekatan yaitu LECI (Lombok as Eco City Isand) dan SuEZ (Sumbawa Eco-Zone). Pendekatan ini merupakan pendekatan pengeloaan yang memberikan arah bagi pemanfaatan sumber daya alam pulau secara berkelanjutan.
Beberapa poin dalam strategi LECI dan SuEZ dapat dikemukan sebagai berikut :

a. Stretegi LECI :

1) Pendekatan pengembangan adalah pendekatan pulau

2) Minimal $30 \%$ dari luas Wilayah merupakan kawasan lindung atau ruang terbuka hijau.

3) Membatasi eksploitasi Pertambangan.

4) Multi infrastruktur berbasis pulau

5) Keunggulan kompetitif sektor parawisata dan argo.

6) Substitusi pemanfaatan sumber daya alam antar Wilayah

b. Strategi SuEZ.

1) Pendekatan pengembangan adalah pendekatan kawasan/zona.

2) Minimal $30 \%$ dari luas Wilayah merupakan kawasan lindung atau ruang terbuka hijau.

3) Multi infrastruktur berbasis kawasan.

4) Keunggulan kompetitif sektor arawisata dan argo

5) Sustansi pemanfaatan sumber daya alam antar kawasan.

Dari kedua strategi tersebut, dapat dilihat pemerintah Provinsi Nusa Tenggara Barat menjadikan parawisata dan argo sebagai sektor keunggulan kompetitif. Di mana sektor tersebut sangat kontra dengan sektor Pertambangan. Sehingga dalam strategi LECI di pulau Lombok terdapat rumusan poin untuk membatasi eksploitasi Pertambangan.

Sebagai tindak lanjut dari peranan Peraturan Pemerintah Nomor 22 tahun 2010 tentang Wilayah Pertambangan dan Peraturan Pemerintah Nomor 23 tahun 2010 tentang Pelaksanaan Kegiatan Usaha Pertambangan Mineral dan Batubara, Pemerintah Provinsi Nusa Tenggara Barat telah mengusulkan luas Wilayah Pertambangan (WP) di Nusa Tenggara Barat seluas $891.590 \mathrm{Ha}$ atau $44,24 \%$ dari total luas daratan Nusa Tenggara Barat. Dengan luas WP di dalam kawasan hutan seluas 479.311,13 Ha atau 53,75\% sedangkan WP di luar kawasan hutan seluas 412.278,87 Ha atau 46,25\%. Luas WP akan berkurang seiring dengan perubahan status 
pengusahaan dari tahapan eksplorasi ke operasi produksi.

Kontribusi sektor Pertambangan dan penggalian mengalami penurunan sejak 2011. Kontribusi tersebut merupakan kumulatif dari penerimaan pajak dan penerimaan bukan pajak. Penerimaan Negara Bukan Pajak (PNBP) meliputi iuran tetap (landrent) dan iuran produksi (royalty) yang kemudian dibagi lagi sebagai dana bagi hasil dari sektor Pertambangan. Selain pajak batuan dan Mineral bukan logam, Kabupaten/Kota juga memungut retribusi atas penerbitan IUP.

Dari penjelasan di atas, diketahui Pertambangan menjadi salah satu sektor pendapatan yang penting bagi daerah. Pada tahun 2016, tercatat pemerintah Provinsi Nusa Tenggara Barat telah mengeluarkan 114 izin usaha Pertambangan bahan galian logam dan batuan. Namun di sisi lain usaha Pertambangan juga mengancam lingkungan hidup sehingga tidak dapat berjalan beriringan dengan sektor parawisata yang menjadi sektor unggulan di Nusa Tenggara Barat khususnya di pulau Lombok.

Kabupaten Lombok Timur merupakan salah satu kabupaten di Nusa Tenggara Barat yang memiliki beberapa destinasi wisata unggulan di Nusa Tenggara Barat, seperti Taman Nasional Gunung Rinjani, Pantai Pink, Pantai Tanggung Bloam, Tanjung Ringgit higga pulau-pulau kecil seperti Gili Kondo dan Gili Sunut. Geliat parawisata di Lombok Timur tersebut dibarengi dengan pemberian izin usaha pertambangan di Kabupaten tersebut, tercatat pada akhir 2016 jumlah penambang batuan yang telah mengantongi izin di Lombok Timur sebanyak 59 pengusahaan. Jumlah tersebut belum termasuk dengan penambangan liar yang tidak memiliki izin.

Terkait pemberian izin pertambangan, sejak diundangkan Undang-Undang nomor 23 tahun 2014 tentang pemerintah daerah. Kewenangan pemberian izin yang sebelumnya dapat dilakukan oleh pemerintah Kabupaten/Kota beralih ke pemerintah Provinsi. Hal tersebut berdasarkan pasal 14 dan 15 Undang-Undang tersebut yang berbunyi:

Pasal 14

(1) Penyelenggaraan urusan pemerintahan bidang kehutanan, kelautan, serta energi dan sumber daya Mineral dibagi antara pemerintah pusat dan daerah Provinsi.

(2) Urusan pemerintahan Bidang Kehutanan sebagaimana dimaksud pada ayat (1) yang berkaitan dengan pengelolaan taman hutan raya Kabupaten/Kota .

(3) Urusan pemerintahan bidan energi dan sumber daya Mineral sebagaimana dimaksud pada ayat (1) yang berkaitan dengan pengelolaan minyak dan gas alam bumi menjadi kewenangan pemerintah pusat.

(4) Urusan pemerintahan bidan energi dan sumber daya Mineral sebagaimana dimaksud pada ayat (1) yang berkaitan dengan pemanfaatan langsung panas bumi dalam daerah Kabupaten/Kota menjadi wewenang daerah Kabupaten/Kota.

(5) Daerah Kabupaten/Kota penghasil dan bukan penghasil mendapatkan bagi hasil dari penyelenggaraan urusan pemerintahan sebagaimana dimakasud pada ayat (1).

(6) Penentuan daerah Kabupaten/Kota penghasil untuk penghitungan bagi hasil keautan adalah hasil kelautan yang berada daam batas wilayah 4 (empat) mil diukur dari garis antai ke arah aut lepas dan/atau ke arah perairan kepulauan.

(7) Daam hal batas wilayah kabupaten/Kota sebagaimana dimaksud pada ayat (6) kurang dari 4 (empat) mil, batas wilayahnya dibagi sama jarak atau diukur sesuai dengan prinsip garis tengah dari daerah yang berbatasan.

Pasal 15:

(1) Pembagian urusan pemerintahan konkuren antara pemerintah pusat dan daerah Provinsi serta daerah Kabupaten/Kota tercantum dalam lampiran yang merupakan bagian yang tidak terpisahkan dari Undang-Undang ini.

(2) Urusan pemerintahan konkuren yang tidak tercantum dalam Undang-Undang ini menjadi kewenangan tiap tingkatan atau susunan pemerintahan yang penentuannya menggunakan prinsip dan kriteria pembagian urusan pemerintahan konkuren sebagaimana dimaksud dalam pasal 13. 
(3) Urusan pemerintahan konkuren sebagaimana dimaksud pada ayat (2) ditetapkan dengan peraturan presiden.

(4) Perubahan terhadap pembagian urusan pemerintahan konkuren antara pemerintah pusat dan daerah Provinsi dan daerah Kabupaten/Kota sebagaimana dimaksud pada ayat (1) yang tidak berakibat terhadap pengalihan urusan pemerintahan konkuren pada tingkatan atau susunan pemerintahan yang lain ditetapkan dengan peraturan pemerintah.

(5) Perubahan sebagaimana dimaksud pada ayat (4) dapat dilakukan sepanjang tidak bertentangan dengan prinsip dan kriteria pembagian urusan pemerintahan konkuren sebagaimana dimaksud dalam pasal 13.

Berdasarkan undangundang tersebut, kewenangan pemberian izin pertambangan tidak lagi dimiliki oleh pemerintah Kabupaten/Kota. Hal tesebut sempat menjadi permasalahan di Lombok Timur, di mana pada tanggal 31 Januari 2015 pemerintah Kabupaten Lombok Timur mengeluarkan Surat Pemberian Izin prinsip penambangan pasir laut oleh Bupati Lombok Timur kepada PT. Dinamika Atria Raya untuk reklamasi Teluk Benoa.

Hal tersebut mendapat protes dari para pegiat lingkungan hidup, karena dinilai pemerintah Kabupaten sudah tidak meiliki lagi kewenangan mengeluarkan Izin Pertambangan sejak Oktober 2014 sejak Undang-Undang nomor 23 tahun 2014 diundangkan. Walaupun pada 2016, pemerintah Provinsi mengluarkan izin pertambangan kepada PT. Dinamika Atria Raya untuk menyedot pasair aut di Perairan Selat Alas Lombok Timur sebanyak 30 juta meter kubik dalam jangka waktu 5 (lima) tahun.

Pemberian Izin Pertambangan yang menjadi kewenangan pemerintah Provinsi juga melahirkan tanggung jawab lebih kepada pemerintah Provinsi, terutama saat proses pemberian izin dilakukan. Dalam Peraturan Daerah Nomor 4 tahun 2012 pasal 15 juga dijelaskan mengenai pengajuan permohonan Wilayah Izin Usaha Pertambangan (WIUP) untuk pertambangan Mineral bukan logam dan batuan, yaitu :
1) Setiap kebgiatan usaha pertambangan Mineral bukan logam atau batuan dapat dilaksanakan pada WIUP dengan cara mengajukan permohonan kepada Gubernur.

2) Permohonan sebagaimana dimaksud pada ayat (1) memperoleh prioritas pertama untuk mendapatkan WIUP apabila telah memenuhi persyaratan:

a. Koordinat geografis sesuai dengan ketentuan sistem informasi geografi yang berlaku secara nasional; dan

b. Membayar biaya pencandangan wilayah dan pencetakan peta.

3) Tata cara, bentuk format permohonan wilayah dan format WIUP diatur lebih lanjut dalam peraturan Gubernur.

Kemudian dari permohonan yang diajukan, pasal 16 ayat (2) dan (3) mengatur tentang kewenangan pemerintah Provinsi dalam emberi izin dan siapa saja yang berhak atas izin tersebut, yaitu :

Ayat (2)

Gubernur memberikan IUP eksplorasi Mineral bukan logam atau batuan kepada badan usaha, koperasi atau perseorangan yang telah memenuhi persyaratan perohonan WIUP sebagaimana dimaksud dalam pasal 15 ayat (2) dan dilengkapi dokumen lingkungan seuai ketentuan perundangUndang yang berlaku.

Ayat (3):

Dalam jangka waktu paling ama 6 (enam) bulan setelah IUP eksplorasi sebagaimana dimaksud pada ayat (1) dan ayat (2) ditetapkan, pemeang IUP wajib memulai kegiatannya.

Jangka waktu yang diberikan terhadap Izin Usaha Pertambangan eksplorasi batuan paling lama 3 (tiga) tahun, meliputi kegiatan penyelidikan umum 1 (satu) tahun, eskplorasi 1 (satu) tahun dan studi kelayakan 1 (satu) tahun. Dengan luas paling sedikit 5 (lima) hektar dan paling banyak 5.000 (lima ribu) hektar. Sedangkan untuk jangka waktu IUP operasi produksi batuan paling lama 5 (lima) tahun dan dapat diperpanjang 2 (dua) kali dan masing-masing 2 (dua) tahun dengan 
luas wilayah paling banyak 1000 (seribu) hektar.

Salah satu bentuk kewajiban pemegang IUP eksplorasi adalah menyampaian laporan kegiatan kepada Gubernur secara berkala, yaitu Triwuan, Semester dan tahunan. Melalui laporan tersebut Gubernur melakukan evaluasi melalui dinas terkait.

Dengan kondisi daerah yang terus membangun, usaha pertambangan galian batuan menjadi primadona bagi pertambangan rakyat. Disini peran pemerintah menjadi sangat penting, terutama kaitannya dengan kewenangan memberikan izin usaha pertambangan. Izin usaha pertambangan harus dibarengi dengan adanya regulasi-regulasi terkait kewajiban dan hak dari pemberi izin dan penerima izin.

Dalam Perda Nomor 2 tahun 2012, juga mengatur hak dan kewajiban dari pemegang IUP. Pemegang IUP berhak untuk melakukan sebagian atau seuruh tahapan usaha pertambangan, baik kegiatan eksplorasi maupun kegiatan operasi produksi sesuai dengan IUP yang dimiliki. Sedangkan kewajiban yang dimiliki:

1) Melaksanakan sosialisasi kepada masyarakat baik sebelum maupun selama kegiatan usaha dilaksanakan minimal sekali dalam 6 (enam) bulan;

2) Mematuhi peraturan perundangUndangna di bidang kesehatan dan keselamatan kerja pertambangan, perlindungan lingkungan hidup, kehutanan dan memenuhi standarstandar yang berlaku;

3) Melaksanakan pengelolaan dan pemantauan lingkungan pertambangan termasuk kegiatan reklamasi dan pasca tambang.

4) Meningkatkan nilai tambah sumber daya Mineral dan/atau Batubara dalam pelaksanaan penambangan, pengolahan dan pemurnian, serta pemanfaatan Mineral dan Batubara;

5) Mengutamakan pemanfaatan tenaga kerja setempat, barang dan jasa dalam negeri sesuai peraturan perundang-Undangan;

6) Melaksanakan program pengembangan dan pemberdayaan masyarakat sekitar tambang, yang direncakana dan disetujui bersama antara perusahaan dan pemerintah Provinsi;

7) Memberikan laporan tertulis secara berkala atas rencana kerja dan pelaksanaan kegiatan usaha pertambangan Mineral dan Batubara kepada gubernur;

8) Membayar pendapatan negara dan pendapatan daerah sesuai peraturan perundang-Undangan; dan

9) Menggunakan perusahaan jasa pertambangan lokal;

Peraturan daerah Provinsi Nusa Tenggara Barat nomor 4 tahun 2012 tentang pengelolaan pertambangan Mineral dan Batubara mengamanatkan pengembangan dan pemberdayaan masyarakat terutama masyarakat disekitar wilayah Izin Usaha Pertambangan. Hal tersbut tercanum dalam pasal 53:

1) Pemegang IUP wajib menyusun program pengembangan dan pemberdayaan masyarakat di sekitar WIUP.

2) Program sebagaimana dimaksud pada ayat (1) harus dikonsultasikan dengan pemerintah Provinsi dan masyarakat setempat.

3) Masyarakat sebagaimana dimaksud pada ayat (2) dapat mengajukan usulan program kegiatan pengembangan dan pemberdayaan masyarakat kepada Bupati/Walikota setempat untuk diteruskan kepada pemerintah Provinsi dan pemegang IUP.

4) Pengembangan dan pemberdayaan masyarakat sebagaimana dimaksud pada ayat (1) diprioritaskan untuk masyarakat di sekitar WIUP yang terkena dampak langsung akibat kegiatan operasionnal penambangan dengan tidak melihat batas administrasi wilayah kecamatan/kabupaten.

5) Program pengembangan dan pemberdayaan masyarakat sebagaimana dimaksud pada ayat (1) dibiayai dari alokasi biaya program pengembangan dan pemberdayaan masyarakat pada anggaran dan biaya setiap tahun yang dikelola oleh pemegang IUP. 
Dari pasal di atas, pemerintah Provinsi Nusa Tenggara Barat mewajibkan pelibatan masyarakat setempat di sekitar tambang dalam program pengembangang dan pemberdayaan masyarakat. Masyarakat dapat mengajukan usulan program kegiatan melalui Bupati/Walikota setempat. Di sini, pemerintah Kabupaten/Kota tempat wilayah Izin Usaha Pertambangan berperan dalam memfasilitasi masyarakat sekitar tambang untuk mendapatkan manfaat lebih dari kegiatan pertambangan tersebut.

Kewajiban pemegang IUP untuk melaksanakan program pengembangan dan pemberdayaan masyarakat, dalam pelaksanannya tetap dilakukan pengawasan oleh pemerintah Provinsi, hal tersebut diamanatkan dalam Pasal 54 Perda momor 4 tahun 2012 yang berbunyi :

1) Mepengang IUP setiap tahun harus menyampaikan rencana dan biaya pelaksanaan program pembangunan dan pemberdayaan masyarakat sebagai bagian dari rencana kerja dan anggaran biaya tahunan kepada Gubernur untuk mendapatkan persetujuan.

2) Setiap pemegang IUP operasi produksi wajib menyampaikan laporan realiasi program pengembangan dan pemberdayaan masyarakat setiap 6 (enam) bulan kepada Gubernur.

Terkait pemberdayaan masyarakat berdasarkan pasal 54 di atas, bentuk tanggung jawab pemerintah dalam penerbitan izin pertambangan lebih bersifat administratif yaitu berupa penyampaian rencana tahunan dan laporan per 6 (enam) bulan.

Selain beberapa tanggung jawab di atas, dalam pemberian izin pertambangan, pemerintah Provinsi juga memiliki tanggung jawab berupa pembinaan dan pengawasan. Bentuk pembinaan dan pengawasan tersebut terdapat dalam pasal 50 peraturan daerah nomor 4 tahun 2012, yakni :

1) Gubernur melakukan pembinaan dan pengawasan terhadap pelaksanaan kegiatan usaha pertambangan Mineral dan Batubara yang dilakukan oleh pemegang IUP.

2) Pelaksanaan pembinaan dan pengawasan sebagaimana dimaksud pada ayat (1) dilaksanakan oleh Dinas dan SKPD teknis terkait lainnya sesuai ketentuan peraturan perundang-Undangan.

3) Pembinaan dan pengawasan sebagaimana dimaksud pada ayat

(1) meliputi :

a. Teknis pertambangan;

b. Pemasaran;

c. Keuangan;

d. Pengolahan data Mineral dan Batubara;

e. Konservasi sumber daya Mineral dan Batubara;

f. Keselamatan dan kesehatan kerja pertambangan;

g. Keselamatan operasi pertambangan;

h. Pengelolaan lingkungan hidup pertambangan, reklamasi dan pasca tambang;

i. Pemanfaatan barang, jasa, teknologi dan kemampan rekayasa dan rancang bangun dalam negeri;

j. Pengembangan tenaga teknis pertambangan;

k. Pengembangan dan pemberdayaan masyarakat setempat;

I. Penguasaan, pengembangan dan penerapan teknologi pertambangan yang menyangkut kepentingan umum;

m. Pengeloaan IUP; dan

n. Jumlah, jenis dan mutu hasil usaha pertambangan.

4) Gubernur memberikan bimbingan dan atau fasilitas usaha pertambangan rakyat yang telah mendapat izin dari Bupati/Walikota sesuai dengan kewenangannya.

5) Gubernur sesuai dengan kewenangannya melaksanakan pembinaan dan pengawasan atas pengelolaan usaha pertambangan lingkup kewenangan Bupati/Walikota.

6) Gubernur sesuai dengan kewenangannya melaksanakan pembinaan, pengawasan, pengendalian dan/atau pengujian 
kualitas Mineral atau Batubara yang beredar di wilayah Provinsi.

Terkait ayat (4) di atas, perlu diingat bahwa sejak diundangkannya UndangUndang Nomor 23 tahun 2014, kewenangan pemberian izin tidak lagi berada pada Bupati/Walikota.

Setelah melalui evaluasi oleh pemerintah Provinsi, apabila dari hasil evaluasi tersebut diketahui pemegang IUP tidak memenuhi kewajiban yang ditetapkan dalam IUP dan/atau tidak memenuhi persyaratan yang ditetapkan oleh peraturan perundangUndangan, maka pemerintah Provinsi berhak mencabut izin usaha pertambangan tersebut.

Seperti yang terjadi di tahun 2016, pemerintah Provinsi melakukan evaluasi terhadap 114 izin usaha pertambangan. Dari jumlah tersebut 109 IUP dicabut karena dinilai tidak lulus evaluasi atau clean and clear. Dengan dibuatnya persyaratan perizinan diharapkan pemegang IUP dapat dilakukan kegiatan sesuai dengan ketentuan yang berlaku. Namun perizinan tanpa adanya pengawasan akan memunculkan pertambangan-pertambangan liar di daerah tersebut.

\section{Bentuk Pengendalian Dampak Pertambangan Bahan Galian Batuan oleh Pemerintah Daerah di Wilayah Lombok Timur.}

Setiap kegiatan pertambangan pasti menimbulkan dampak positif maupun dampak negatif. Dampat positif ari kegiatan dibidang pertambangan adalah² :

1) Memberikan nilai tambah secara nyata kepada pertumbuhan ekonomi nasional.

2) Meningkatkan Pendapatan Asli Daerah (PAD).

3) Menampung tenaga kerja, terutama masyarakat lingkar tambang.

4) Meningkat ekonomi masyarakat lingkar tambang..

5) Meningkatkan usaha mikro masyarakat lingkar tambang.

6) Meningkatkan kualitas SDM masyarakat lingkar tambang.

7) Meningkatkan derajat kesehatan masyarakat lingkar tambang.

2 Halim HS, Hukum Pertambangan Mineral dan Batu Bara, (Jakarta: Sinar Grafika, 2012) hal. 57.
Sedangkan dampak Negatif dari kegiatan pertambangan adalah ${ }^{3}$ :

1. Kehancuran lingkungan hidup;

2. Penderitaan masyarakatada;

3. Menurunnya kualitas hidup masyarakat lokal;

4. Meningkatnya kekerasan terhadap perempuan;

5. Kehancuran ekologi pulau-pulau;

6. Terjadinya pelanggaran HAM pada kuasa pertambangan.

Tahun 2017 jumlah izin pertambangan yang telah dikeluarkan oleh Pemerintah Provinsi Nusa Tenggara Barat di Kabupaten Lombok Timur sebanyak 22 izin usaha pertambangan dan meningkat menjadi 31 izin usaha pertambangan di tahun 2018. Berdasarkan peraturan daerah kabupaten Lombok Timur Nomor 2 tahun 2012 tentang Rencana Tata Ruang Wilayah, daerah yang merupakan wilayah pertambangan masuk dalam kecamatan Pringgasela, kecamatan Pringgabaya, kecamatan Aikmel, kecamatan Wanasaba, kecamatan Labuhan Haji dan kecamatan Suela.

Dampak lingkungan dari kegiatan pertambangan tidak hanya terjadi setelah selesainya kegiatan pertambangan yaitu berupa kerusakan lingkungan dan terganggunya ekologi. Namun berdasarkan informasi Dinas Lingkungan Hidup Kabupaten Lombok Timur, dampak negatif juga terjadi selama kegiatan pertambangan berlangsung, seperti polusi udara dan polusi suara. Hal tersebut terjadi selama proses pertambangan dan pengangkutan.

Dalam peraturan daerah Provinsi Nusa Tenggara Barat nomor 4 tahun 2012 pasal 55, 56 dan 57 mengatur tentang reklamasi dan pasca tambang, yaitu:

Pasal 55:

(1) Pemegang IUP eksplorasi wajib melaksanakan reklamasi.

(2) Pemegang IUP operasi produksi wajib melaksanakan reklamasi dan pasca tambang.

(3) Reklamasi dan/atau pasca tambang sebagaimana dimaksud pada ayat (1) dan ayat (2) dilakukan terhadap lahan terganggu.

(4) Tata laksana reklamasi dan/atau pasca tambang dilakukan sesuai 
dengan perturan perundangUndangan yang berlaku.

Pasal 56:

(1) Guernur memberikan persetujuan atas dokumen reklamasi dan dokumen pasca tambang yang diajukan oleh pemegang IUP eksplorasi.

(2) Persetujuan sebagaimana dimaksud pada ayat (1) diberikan setelah pemegang IUP eksplorasi menyelesaikan tahap studi kelayakan dan dilakukan penilai sesuai dengan ketentuan peraturan perudangundangan.

(3) Pemegang IUP eksplorasi sebagaimana dimaksud pada ayat (2) mengajukan permohonan peningkatan ke tahapan operasi produksi.

Pasal 57:

(1) Pemegang IUP operasi produksi wajib menyetor jaminan reklamasi dan jaminan pasca tambang ditetapkan oleh gubernur.

(2) Besaran jaminan reklamasi dan jaminan pasca tambang ditetapkan oleh Gubernur.

(3) Ketentuan lebih lanjut mengenai bentuk, tata cara penyetoran dan pencairan jaminan reklamasi dan jaminan pasctambang diatur dengan peraturan Gubernur.

Berdasarkan pasal di atas, perda nomor 4 tahun 2012 mengamanatkan kewajiban reklamasi bagi para pemegang izin usaha pertambangan. Reklamasi lahan ditujukan untuk memulihkan kondisi lahan sehingga mendekati kondis awal sebelum penambangan. Kegiatan ini dilakukan sepanjang tahapan usaha pertambangan untuk menata, memulihkan, dan memperbaiki kualitas lingkungan dan ekosistem agar dapat berfungsi kembali sesuai peruntukannya.

Berdasarkan pasal di atas juga secara ekplisit disebutkan bahwa kewenangan memberikan persetujuan dan menerima jaminan reklamasi serta jaminan pasca tambang berada pada pemerintah Provinsi dalam hal ini Gubernur. Sedangkan tidak diatur kewenagnan pemerintah kabupaten dalam melakukan pengawasan maupun pengendalian reklamasi dan pasca tambang.
Bentuk tanggungjawab pemerintah kabupaten hanya terbatas pada pemberian izin lingkunga yang akan dijadikan dasar bagi pemerintah Provinsi untuk menerbitkan izin usaha pertambangan.

Adapaun syarat-syarat yang harus dipenuhi untuk mendapatkan izin lingkungan adalah sebagai berikut:

1) Draf Dokument UKL-UPL.

2) Persetujuan Bupati.

3) Surat Rekomendasi Tata Ruang.

4) Surat Permohonan Izin Lingkungan.

5) NPWP Perusahaan/Instansi.

6) Identitas diri Pemilik/Penanggung Jawab.

7) Berita Acara Pemeriksaan Lokasi.

8) Bukti Kepemilikan Lahan.

9) Rekomendasi Desa.

10) Rekomendasi Camat.

11) Bukti Sosialisa/Persetujuan masyarakat.

12) Denah Lokasi dan Site Plan.

13) Surat Kuasa dari Pemrakarsa Kepada Konsultan.

Dasar hukum kewajiban memiliki izin lingungan sebagai persyaratan permohonan mendapatkan izin usaha pertambangan adalah pasal 36 ayat (1) Undang-Undang nomor 32 tahun 2009 tentang Perlindungan dan Pengelolaan Lingkungan Hidup (UUPPLH) menyebutkan bahwa: "Setiap usaha dan/atau kegiatan yang wajib memiliki Amdal atau UKL-UPL wajib memiliki izin lingkungan".

Dari pemaparan di atas dapat disimpulkan bahwa pemerintah kabupaten Lombok Timur tidak memiliki kewenangan dalam pengendalian dampak pertambangan bahan galina batuan, walaupun kegiatan pertambangan tersebut dilakukan di wilayah Lombok Timur. Namun kewenangan pengendalian dampak pertambangan bahan galian batuan berada di pemerintah Provinsi Nusa Tenggara Barat.

\section{KESIMPULAN}

Adapun kesimpulan yang dapat kami tarik dari uraian-uraian pada skripsi ini akan tertuang dalam bentuk tanggung jawab Pemerintah Provinsi Nusa Tenggara Barat dalam memberikan izin ditinjau dari UndangUndang Nomor 23 tahun 2014 adalah sebagai berikut: Bahwa dengan diundangkan Undang-Undang Nomor 23 tahun 2014 tentang pemerintahan daerah, kewenangan 
untuk mengeluarkan Izin Usaha Pertambangan (IUP) tidak lagi dikeluarkan oleh pemerintah Kabupaten/Kota, akan tetapi dikeluarkan oleh Pemerintah Provinsi. Tanggung jawab Pemerintah Provinsi Nusa Tenggara Barat dalam mengeluarkan izin pertambangan bahan gaian batuan telah diatur dalam Peraturan daerah Provinsi Nusa Tenggara Barat nomor 4 tahun 2012 tentang Pengelolaan Pertambangan Mineral dan Batubara. Dalam peraturan daerah nomor 4 tahun 2012 tentang pengelolaan pertambangan Mineral dan Batubara, telah diatur bentuk tanggung jawab pemerintah Provinsi mulai dari pemberina izin usaha pertambangan hingga pengawasan reklamasi dan pasca tambang. Pengendalian dampak pertambangan bahan galian batuan di wilayah Lombok Timur sebagaimana diatur dalam Perda momor 4 tahun 2012 tersebut berada di pemerintah Provinsi Nusa Tenggara Barat. Pemerintah kabupaten Lombok Timur tidak berwenang melakukan pengawasan maupun pengendalian dampak pertambangan bahan galian batuan diwilayahnya. Bentuk pengenalian dampak pertambangan bahan galian batuan berdasarkan peraturan daerah nomor 4 tahun 2012 hanya bersifat administratif.

Pemerintah Provinsi Nusa Tenggara Barat dalam hal pengendalian dampak lingkungan seyogyanya melibatkan pemerintah KabupatenKota, hal ini dikarenakan pemerintah Kabupaten/Kota-lah yang memilik perangkat daerah disekitar wilayah pertambangan, sehingga lebih mudah dalam pengawasan.

Fakta dilapangan menunjukkan bahwa sulitnya proses perizinan mengakibatkan banyaknya penambangan liar. Dengan maraknya penambangan liar pemerintah Provinsi akan mengalami kesulitan dalam hal pengawasan. Sehingga untuk mengurangi semakin maraknya penambangan liar bukan dengan mempersulit perizinan namun perlu adanya pembatasan wilayah penambangan.

\section{DAFTAR PUSTAKA}

HS, Salim, Hukum Pertambangan dan Batu Bara, Jakarta : Sinar Grafika 2002

Adi, Dwi Primilono, 2016, Konsep Hukum Pertambangan Rakyat Studi di
Kabupaten Lombok Barat, Mataram : Jurnal IUS 2016.

Paramita, Rahadian P, Pengelolaan Pertambangan Mineral di Provinsi Nusa Tenggara Barat, Makalah Monitoring dan Evaluasi Pengelolaan Usaha Pertambangan di Provinsi Nusa Tenggara Barat Dalam Rangka Koordinasi-Supervisi Kementerian ESDM RI-Komisi Pemberantasan Korupsi (KPK), 2015

Indonesia, Undang-Undang Pertambangan Mineral dan Batubara, UUD Nomor 4 tahun 2009, TLN Nomor 4959 tahun 2009.

Indonesia, Undang-Undang tentang Perlindungan dan Pengelolaan Lingkungan Hidup, UU nomor 32 tahun 2009, TLN nomor 5059 tahun 2009.

Indonesia, Undang-Undang Tentang Pemerintahan daerah, UU Nomor 22 tahun 2014, TLN nomor 5587 tahun 2014.

Indonesia, Peraturan Pemerintah Nomor 22 tahun 2010 tentang Wilayah Pertambangan, TLN nomor 5110 tahun 2010.

Nusa Tenggara Barat, Peraturan Daerah Tentang Pengelolaan Pertambangan Mineral dan Batubara, Perda Nomor 4 tahun 2012, TLD nomor 81 tahun 2012.

Lombok Timur, Salinan Peraturan Bupati Nomor 30 Tahun 2014 Tentang Upaya Pengelolaan Lingkungan Hidup dan Upaya Pemantauan Lingkungan Hidup dan Surat Pernyataan Kesanggupan Pengelolaan dan Pemantauan Lingkungan Hidup.

https://id.wikipedia.org/wiki/Sejarah_perminy akan_di_Indonesia 